\title{
Antibacterial Screening of Endophytic Fungus Xylaria sp. derived from Andrographis paniculata (Sambiloto)
}

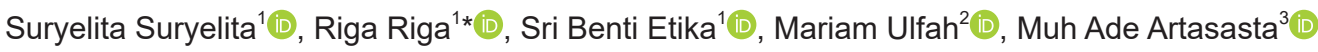 \\ ${ }^{1}$ Department of Chemistry, Faculty of Mathematics and Natural Sciences, Universitas Negeri Padang, Padang, Indonesia; \\ ${ }^{2}$ Department of Pharmacy, STIKES Muhammadiyah Cirebon, Cirebon, Indonesia; ${ }^{3}$ Department of Biotechnology, Faculty of \\ Mathematics and Natural Sciences, University Negeri Malang, Malang, Indonesia
}

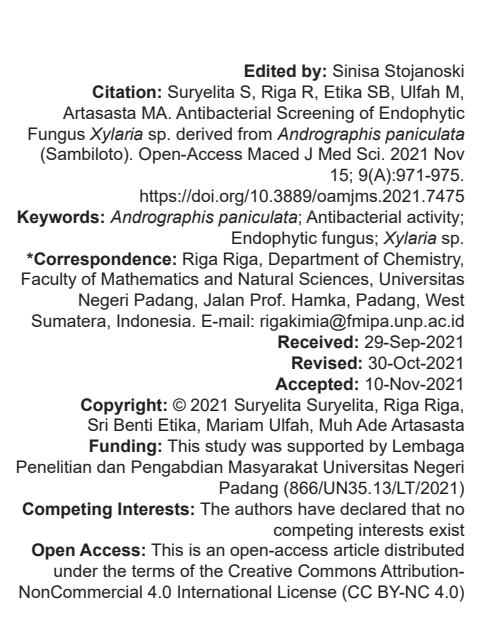

\section{Abstract}

AIM: The purpose of this research is to evaluate the antibacterial activity of endophytic fungi derived from the flowers of Andrographis paniculata (Sambiloto).

METHODS: The endophytic fungi were obtained following the dilution method with potato dextrose agar as media Four isolates of fungi have been obtained and then fermented with rice media for 3 weeks. The fermented fungi were extracted with ethyl acetate (EtOAc) and evaporated to yield the EtOAc extract. All EtOAc extracts were evaluated for their antibacterial activity using agar diffusion method.

RESULTS: The results indicated that the EtOAc extract from fungus RG-2 was the potential source of antibacterial compounds. Molecular identification showing fungus RG-2 was Xylaria sp.

CONCLUSION: Further investigation of the antibacterial compounds produced by fungus Xylaria sp. derived from the flowers of $A$. paniculata will be performed in the future. To the best of our knowledge, endophytic fungal Xylaria $\mathrm{sp}$. is firstly isolated from $A$. paniculata.

\section{Introduction}

Andrographis paniculata known as Sambiloto in Indonesia is a plant species in the family Acanthaceae. A. paniculata are found in subtropical areas including China, India, and Indonesia [1], [2]. A. paniculata has been widely used as medicinal herbs, such as treatment of diabetes, fever, diarrhea, skin diseases, flatulence, colic, and influenza [3], [4]. Previous phytochemical research of $A$. paniculata resulted in diverse groups of secondary metabolites with various biological activities, including antibacterial [5], [6], [7]. According to the report from the World Health Organization (WHO), many antibiotic-resistant infections occur in the world each year. Based on this data, research of drug discovery targeting drugresistant bacteria is important to occur. One of the sources for producing the antibacterial compounds is endophytic fungi from $A$. paniculata.

Endophytic fungi are microorganisms living in internal plant tissues without causing negative effects for their host plants [8], [9], [10], [11]. Endophytic fungi are sources of a variety of bioactive secondary metabolites where one of them is antibacterial compounds [9], [12], [13]. Previous research of antibacterial activity from endophytic fungi obtained from various host plants has been reported. Ethyl acetate (EtOAc) extract from 24 endophytic fungi obtained from Garcinia mangostana showed antibacterial activity against some pathogenic bacteria [14].

Furthermore, endophytic fungi derived from roots, leaves, and stems of $A$. paniculata also exhibited antibacterial activity [15]. A new benzochromen derivative isolated from fungus Aspergillus sp. from the leaves of $A$. paniculata showing antibacterial activity against Staphylococcus aureus, Escherichia coli, Shigella dysenteriae, and S. typhi [16]. These data indicated that the endophytic fungi associated with $A$. paniculata have the potential as a source of antibacterial compounds. In the present study, we investigated the phytochemical screening of endophytic fungi isolated from flowers of $A$. paniculata and their antimicrobial activity against $E$. coli, $S$. aureus, and Streptococcus pyogenes following the disc diffusion method. One of the most potential fungi in this study was identified molecularly as Xylaria sp. For your information, the research of antibacterial screening 
from the EtOAc extract of fungus Xylaria sp. obtained from the flowers of $A$. paniculata has not been reported.

\section{Materials and Methods}

\section{Sample preparation}

The flowers of $A$. paniculata were collected on January 2021 from Padang Pariaman, West Sumatera, Indonesia. Inoculation of the flowers was carried out an hour after collection in the laboratory.

\section{Isolation of endophytic fungi from the}

\section{flowers of $A$. paniculata}

The isolation of endophytic fungi from the flowers of $A$. paniculata followed the reported method [17]. The fresh flowers of $A$. paniculata were sterilized with ethanol $70 \%$ for $45 \mathrm{~s}$ and $\mathrm{NaClO} 3.5 \%$ for $30 \mathrm{~s}$. The sterile flowers were placed on the potato dextrose agar (PDA) media as a negative control. Then, the internal tissue of flowers was inoculated on the PDA media and incubated at $28^{\circ} \mathrm{C}$. After 7 days, the endophytic fungi were transferred to the other PDA media to give the single isolate. All steps were processed under aseptic conditions. Based on the morphology of fungi, four endophytic fungi (RG-1, RG-2, RG-3, and RG-4) have been isolated from the flowers of $A$. paniculata.

\section{Fermentation and extraction}

The four purified fungi $(2 \times 2 \mathrm{~cm})$ on agar media were transferred to $250 \mathrm{~mL}$ Erlenmeyer flasks containing rice media (25 g rice $/ 30 \mathrm{~mL}$ aquadest). Endophytic fungi were cultivated at $28^{\circ} \mathrm{C}$ for $1,2,3$, and 4 weeks under stationary conditions [17]. The cultivated endophytic fungi were repeatedly extracted with EtOAc to give the crude extract. Endophytic fungi with potential cultivation time were analyzed for their antibacterial activity and phytochemical screening.

\section{Screening for antibacterial activity}

The EtOAc extract of each fungus was evaluated for the antibacterial activity following the disc diffusion method [18], [19] against three bacteria ( $E$. coli, S. aureus, and Streptococcus pyogenes). All tested bacteria were isolated from patients and identified by morphological and biochemical tests in Universitas Indonesia. Fifteen milliliters of the MHA media were poured into Petri dishes followed by inoculation of bacteria on the MHA media. Each EtOAc extract with the series concentrations $(1 \%, 3 \%$, and $5 \%$ ) dissolved in methanol. Amoxicillin was used as a positive control and methanol was used as a negative control. Sterile paper discs $(6 \mathrm{~mm}$ ) loaded with $20 \mu \mathrm{L}$ of the samples were placed onto the surface of the agar. After $24 \mathrm{~h}$ incubation, the diameter of the zone of inhibition was measured and recorded. Each experiment was performed in triplicate. The inhibition zone of each extract was analyzed statistically and presented as mean \pm standard deviation.

\section{Minimum inhibitory concentration (MIC) of the EtOAc extract}

MIC assay was evaluated for the EtOAc extract of fungus RG-2 following microplate broth dilution method (Radji et al., 2011). Overnight culture of tested bacteria (approximately $10^{6} \mathrm{CFU}$ ) was seeded into the wells. The crude extract was tested at serial concentrations from 400 to $3.125 \mu \mathrm{g} / \mathrm{mL}$ and then incubated at $37^{\circ} \mathrm{C}$. After $24 \mathrm{~h}, \mathrm{MIC}$ was determined as the least concentration of the extract inhibiting the growth of the tested bacteria. Amoxicillin was used as a positive control.

\section{Phytochemical screening of EtOAc extract}

All EtOAc extracts of endophytic fungi were evaluated for their chemical constituents following the standard method [20] with modification. The aim of this step is to know the presence of alkaloids, phenolic compounds, terpenoids, and steroids from each extract.

\section{Steroid and terpenoid screening}

The EtOAc extract was dissolved with ammonia-chloroform and $\mathrm{H}_{2} \mathrm{SO}_{4} 2 \mathrm{~N}$ and shaken to form two layers. The bottom layer was evaporated and added anhydrous acetic acid and $\mathrm{H}_{2} \mathrm{SO}_{4}$ p.a. The presence of steroid will be shown by green-blue color, while the presence of terpenoid will be indicated by red color.

\section{Alkaloid screening}

The top layer in steroid and terpenoid screening was transferred into three test tubes and added with Dragendorff reagent, Mayer reagent, and Wagner reagent, respectively. Alkaloid positive will be shown by a brown precipitate, a white precipitate, and an orange precipitate, respectively.

\section{Phenolic compound screening}

The EtOAc extract was dissolved with $\mathrm{FeCl}_{3} 1 \%$. The presence of phenolic compounds will be shown by the pink color of the filtrate. 


\section{Identification of fungus}

Identification of endophytic fungus was carried out using analyses of the Internal Transcribed Spacer (ITS) region of the ribosomal DNA [21]. After $72 \mathrm{~h}$ cultivation of endophytic fungus on PDB media, the DNA of fungus was extracted using nucleon PHYTO pure and then amplified using primer ITS 4 (5'- TCC TCC GCT TAT TGA TAT GC-3') and ITS 5 (5'- GGAAGT AAAAGT CGT AAC AAG G-3). The method of polyethylene glycol precipitation was used for the purification of the PCR product. Furthermore, the PCR product was sequenced with an automated DNA sequencer. The sequencing data were trimmed and assembled with the BioEdit program and then blasted at National Center for Biotechnology Information. Constructing the phylogenetic tree following neighbor joining method with a bootstrap value of 1.000 replication used MEGA 7.0 software [22].

\section{Results and Discussion}

Based on reported phytochemical research, hundreds of secondary metabolites including flavonoids, terpenoids, steroids, and alkaloids have been discovered from $A$. paniculata, some of which were novel compounds. Some isolated compounds reported various modes of biological activities in vivo as well as in vitro, such as antibacterial, anticancer, antiviral, and anti-HIV [5]. In our previous study, an endophytic fungus labeled with RG-2 obtained from the twigs of $A$. paniculata exhibited antibacterial activity against three tested bacteria, E. coli, S. aureus, and S. pyogenes [20]. To continue our study for searching antibacterial sources from endophytic fungi derived from host plant $A$. paniculata, we investigated the antibacterial screening from endophytic fungi obtained from the flowers of $A$. paniculata in this study.

Four single strains of endophytic fungi (RG-1, RG-2, RG-3, and RG-4) were isolated from the flowers of A. paniculata. Optimization of endophytic fungi to produce secondary metabolite was carried out by analyzing the EtOAc extract mass (Figure 1). These data indicated that the optimum cultivation time of all fungi isolated from flowers of $A$. paniculata is 3 weeks. These data indicated that the 3 weeks were the stationary phase of fungal growth. The stationary phase of fungal growth is a phase where cell division and cell death are equal. In this phase, the enzymes responsible for obtaining secondary metabolites accumulate, so secondary metabolites will be yielded significantly [9], [12].

Antibacterial activity of the EtOAc extract from all fungi showed that all of them were active against E. coli, S. aureus, and S. pyogenes. All extracts of endophyte fungi isolates were able to inhibit the growth of $E$. coli and S. pyogenes and three extracts were active

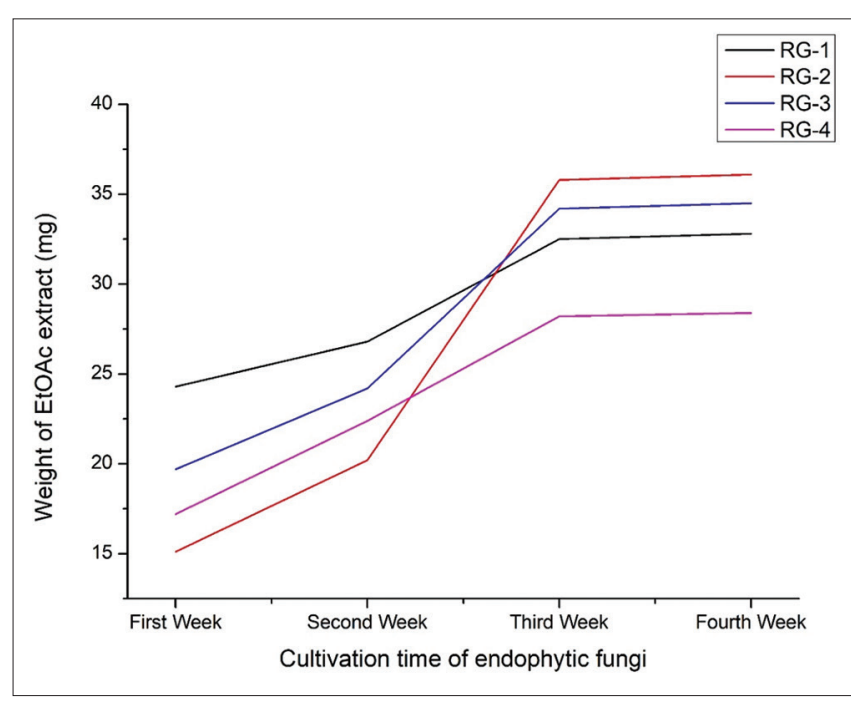

Figure 1: Optimization of cultivation time of endophytic fungi

against $S$. aureus. Data of the inhibition zone in Table 1 showed that the antibacterial activity increases with a higher concentration of extract. Increasing the number of bioactive metabolites will have a positive impact on the potential of the EtOAc extract as an antibacterial source [23]. The EtOAc extract of endophytic fungus RG-2 showed the largest inhibition zone against all tested bacteria in the concentration of $5 \%$ (inhibition zones of $10.67,12.33$, and $13.00 \mathrm{~mm}$, respectively).

Table 1: Inhibition zone of endophytic fungal extract

\begin{tabular}{|c|c|c|c|c|}
\hline Fungus & Concentration (\%) & E. coli $(\mathrm{mm})$ & S. aureus $(\mathrm{mm})$ & S. pyogenes $(\mathrm{mm})$ \\
\hline \multirow[t]{3}{*}{ RG-1 } & 5 & $6.67 \pm 1.53$ & $8.67 \pm 1.53$ & $9.33 \pm 0.58$ \\
\hline & 3 & $5.33 \pm 0.58$ & $7.67 \pm 1.15$ & $6.67 \pm 0.58$ \\
\hline & 1 & $4.33 \pm 0.58$ & $6.33 \pm 1.15$ & $5.33 \pm 1.53$ \\
\hline \multirow[t]{3}{*}{ RG-2 } & 5 & $10.67 \pm 0.58$ & $12.33 \pm 0.58$ & $13.00 \pm 1.00$ \\
\hline & 3 & $8.33 \pm 0.58$ & $7.67 \pm 0.58$ & $9.33 \pm 0.58$ \\
\hline & 1 & $6.33 \pm 0.58$ & $5.67 \pm 0.58$ & $7.33 \pm 0.58$ \\
\hline \multirow[t]{3}{*}{ RG-3 } & 5 & $8.67 \pm 1.15$ & $9.33 \pm 0.58$ & $7.33 \pm 0.58$ \\
\hline & 3 & $6.33 \pm 0.58$ & $7.33 \pm 0.58$ & $5.33 \pm 1.15$ \\
\hline & 1 & $4.33 \pm 0.58$ & - & $4.67 \pm 0.58$ \\
\hline \multirow[t]{3}{*}{ RG-4 } & 5 & $7.67 \pm 0.58$ & - & $8.67 \pm 0.58$ \\
\hline & 3 & $6.33 \pm 0.58$ & - & $6.33 \pm 0.58$ \\
\hline & 1 & $5.33 \pm 0.58$ & - & $4.33 \pm 0.58$ \\
\hline \multicolumn{2}{|c|}{ Positive Control } & $13.67 \pm 0.58$ & $14.33 \pm 0.58$ & $15.67 \pm 0.58$ \\
\hline
\end{tabular}

Furthermore, the MIC values of the EtOAc extract of fungus RG-2 were determined by the dilution method. The MIC values of the EtOAc extract are presented in Table 2.

Table 2: The MIC values of the EtOAc extract of fungus RG-2

\begin{tabular}{lll}
\hline Tested bacteria & $\mathrm{MIC}(\mu \mathrm{g} / \mathrm{mL})$ & \\
\cline { 2 - 3 } & EtOAc Extract & Amoxicillin \\
\hline E. coli & 25 & 6.25 \\
S. aureus & 12.5 & 6.25 \\
S. pyogenes & 25 & 12.5 \\
\hline
\end{tabular}

Interestingly, the EtOAc extract from fungus RG-2 had MIC values of $12.5 \mu \mathrm{g} / \mathrm{ml}$ against $M$. luteus, $25 \mu \mathrm{g} / \mathrm{mL}$ against $E$. coli, and $25 \mu \mathrm{g} / \mathrm{mL}$ against $S$. pyogenes. They were only 2 and 4 times higher than amoxicillin as a positive control.

Table 3: Phytochemical screening of endophytic fungal extract

\begin{tabular}{lllll}
\hline & RG-1 & RG-2 & RG-3 & RG-4 \\
\hline $\begin{array}{llll}\text { Steroid/terpenoid } \\
\text { Alkaloid }\end{array}$ & ++ & +++ & + & + \\
$\quad$ Dragendorff & ++ & ++ & + & + \\
$\quad$ reagent & & & & \\
Mayer reagent & + & ++ & + & + \\
$\quad$ Wagner reagent & + & ++ & + & + \\
Phenolic compound & + & ++ & ++ & - \\
\hline
\end{tabular}


Table 4: Estimation of evolutionary divergence between sequences using the Kimura 2-parameter model

\begin{tabular}{|c|c|c|c|c|c|c|c|c|c|c|c|c|}
\hline & Accession number & 1 & 2 & 3 & 4 & 5 & 6 & 7 & 8 & 9 & 10 & 11 \\
\hline 1 & RG2 & & & & & & & & & & & \\
\hline 2 & JQ341083.1 & 0.004 & & & & & & & & & & \\
\hline 3 & JQ341076.1 & 0.022 & 0.022 & & & & & & & & & \\
\hline 4 & JQ341078.1 & 0.011 & 0.01 & 0.561 & & & & & & & & \\
\hline 5 & MT908489.1 & 0.021 & 0.021 & 0.101 & 0.021 & & & & & & & \\
\hline 6 & JF795289.1 & 0.018 & 0.018 & 0.716 & 0.018 & 0.705 & & & & & & \\
\hline 7 & KY250407.1 & 0.022 & 0.022 & 0.002 & 0.022 & 0.099 & 0.715 & & & & & \\
\hline 8 & EU010005.1 & 0.021 & 0.021 & 0.592 & 0.021 & 0.628 & 0.746 & 0.591 & & & & \\
\hline 9 & MK247797.1 & 0.075 & 0.01 & 0.561 & 0.012 & 0.622 & 0.744 & 0.560 & 0.557 & & & \\
\hline 10 & HM535386.1 & 0.036 & 0.007 & 0.604 & 0.081 & 0.634 & 0.746 & 0.603 & 0.559 & 0.081 & & \\
\hline 11 & MW045999.1 & 0.089 & 0.011 & 0.592 & 0.099 & 0.582 & 0.738 & 0.591 & 0.553 & 0.097 & 0.083 & \\
\hline 12 & MK304420.1 & 0.068 & 0.065 & 0.559 & 0.012 & 0.628 & 0.750 & 0.558 & 0.549 & 0.008 & 0077 & 0.093 \\
\hline
\end{tabular}

These results presented in this study indicated that fungal RG-2 bears a potent antibacterial activity and could be a valuable candidate for the discovery of lead compounds for antibacterial purpose.

The antibacterial activity of the EtOAc extract from fungus RG-2 is related to the presence of bioactive metabolites. Phytochemical screening of each EtOAc extract showing the presence of steroids/terpenoids, alkaloids, and phenolic compounds is presented in Table 3. Alkaloids inhibited bacterial growth by disrupting the peptidoglycan in bacterial cells. The mechanism of terpenoids as antibacterial agents disrupted the formation of the membrane. It will make the membrane will not be perfectly formed [24]. The factors of phenolic compounds as an antibacterial source are lipophilicity, electronic activity, and polyphenol content. Phenolic compounds will inhibit the reverse transcription enzymes and DNA topoisomerase [25], [26], [27].

Based on this antibacterial and phytochemical screening, fungus RG-2 has the greatest secondary metabolites with antibacterial activity. Molecular identification of fungal RG-2 showed that RG-2 was Xylaria sp. with sequence identities of $99 \%$. The phylogenetic tree was constructed using neighbor-joining method with a bootstrap value of 1.000 (Figure 2). RG-2 is clustered with Xylaria sp. JQ341083 from West African. The genetic difference between Xylaria sp. JQ341083 is only $0.4 \%$ according to the Kimura2-parameter model (Table 4). Meanwhile, the genetic difference among the other fungi is more than $1.1 \%$.

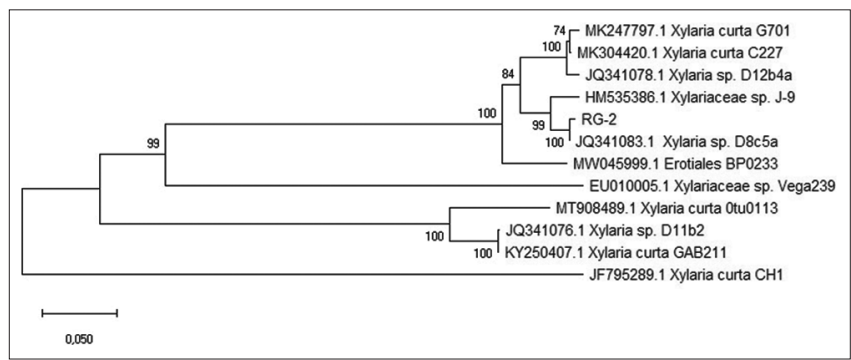

Figure 2: The phylogenetic tree inferred using the neighbor-joining method of ITS sequence of fungus RG-2 derived from A. paniculata and its allied taxa

Genus Xylaria has been previously reported for its chemical constituents and has proven to be a potential source of antibacterial compounds. A coumarin derivative, 7-amino-4-methylcoumarin, exhibited strong antibacterial activity against 10 bacteria, including
S. aureus, E. coli, S. typhi, Salmonella typhimurium, S enteritidis, Aeromonas hydrophila, Yersinia sp., Vibrio anguillarum, Shigella sp., and Vibrio parahaemolyticus with MIC less than $25 \mu \mathrm{g} / \mathrm{mL}$ [28]. In addition, two cyclopentapeptides, xylapeptides $A$ and $B$, showed strong antibacterial activity against Bacillus subtilis and $B$. cereus (MIC values $<12.5 \mu \mathrm{g} / \mathrm{mL}$ ) [29]. These reported studies indicated that the EtOAc extract of Xylaria sp. derived from the flowers of $A$. paniculata may also produce various secondary metabolites with antibacterial activity. Further investigation of the antibacterial compounds isolated from fungal Xylaria sp. from $A$. paniculata needs to be done in the future.

\section{Conclusions}

An endophytic fungus RG-2, identified as Xylaria sp., was obtained from the flowers of A. paniculata having broad antibacterial activity against E. coli, S. aureus, and S. pyogenes. It is the firstly isolated Xylaria sp. from $A$. paniculata. Further study to identify secondary metabolites that play a role in the antibacterial properties of the EtOAc extract from fungal Xylaria sp. obtained from the lowers of $A$. paniculata needs to be continued.

\section{Acknowledgments}

The authors would like to thank Lembaga Penelitian dan Pengabdian Masyarakat Universitas Negeri Padang for funding this work with a contract number: 866/UN35.13/LT/2021.

\section{References}

1. Hossain MS, Urbi Z, Sule A, Rahman KM. Andrographis paniculata (Burm. f.) Wall. ex Nees: A review of ethnobotany, phytochemistry, and pharmacology. Sci World J. 
2014;2014:274905. https://doi.org/10.1155/2014/274905 PMid:25950015

2. Joselin J, Jeeva S. Andrographis paniculata: A review of its traditional uses, phytochemistry and pharmacology. Med Aromat Plants. 2014;3(4):1-15. https://doi. org/10.4172/2167-0412.1000169

3. Okhuarobo A, Falodun JE, Erharuyi O, Imieje V, Falodun A, Langer P. Harnessing the medicinal properties of Andrographis paniculata for diseases and beyond: Areview of its phytochemistry and pharmacology. Asian Pac J Trop Dis. 2014;4(3):213-22. https://doi.org/10.1016/s2222-1808(14)60509-0

4. Utaminingrum W, Nofrianti N, Hartanti D. Ethnomedicinal survey of traditional antidiabetic plants in Baturraden and Sumbang. Medisains. 2020;18(2):43-51. https://doi.org/10.30595/ medisains.v18i2.7169

5. Karthik K, Dhanuskodi S, Gobinath C, Prabukumar S, Sivaramakrishnan S. Andrographis paniculata extract mediated green synthesis of $\mathrm{CdO}$ nanoparticles and its electrochemical and antibacterial studies. J Mater Sci Mater Electron. 2017;28(11):7991-8001. https://doi.org/10.1007/ s10854-017-6503-8

6. Rajalakshmi V, Cathrine L. Phytochemical screening and antimicrobial activity of ethanolic extract of Andrographis paniculata. J Pharmacogn Phytochem. 2016;5(2):175-7.

7. Singha PK, Roy S, Dey S. Antimicrobial activity of Andrographis paniculata. Fitoterapia. 2003;74(7-8):692-4. https://doi. org/10.1016/s0367-326x(03)00159-x

PMid: 14630176

8. Jia M, Chen L, Xin HL, Zheng CJ, Rahman K, Han $\mathrm{T}$, et al. A friendly relationship between endophytic fungi and medicinal plants: A systematic review. Front Microbiol. 2016;7:906. https:// doi.org/10.3389/fmicb.2016.00906

PMid:27375610

9. Keller NP. Fungal secondary metabolism: Regulation, function and drug discovery. Nat Rev Microbiol. 2019;17(3):167-80. https://doi.org/10.1038/s41579-018-0121-1 PMid:30531948

10. Riga R, Happyana N, Hakim EH. Chemical constituents of Pestalotiopsis microspora HF 12440. J Appl Pharm Sci. 2019;9(1):108-24. https://doi.org/10.7324/japs.2019.90116

11. Schulz B, Haas S, Junker C, Andrée N, Schobert M. Fungal endophytes are involved in multiple balanced antagonisms. Curr Sci. 2015;109(1):39-45.

12. Calvo AM, Wilson RA, Bok JW, Keller NP. Relationship between secondary metabolism and fungal development. Microbiol Mol Biol Rev. 2002;66(3):447-59. https://doi.org/10.1128/ mmbr.66.3.447-459.2002

PMid:12208999

13. Khiralla A, Spina R, Varbanov M, Philippot S, Lemiere P, SlezackDeschaumes S, et al. Evaluation of antiviral, antibacterial and antiproliferative activities of the endophytic fungus Curvularia papendorfii, and isolation of a new polyhydroxyacid. Microorganisms. 2020;8(9):1353. https://doi.org/10.3390/ microorganisms 8091353 PMid:32899776

14. Radji M, Sumiati A, Rachmayani R, Elya B. Isolation of fungal endophytes from Garcinia mangostana and their antibacterial activity. Afr J Biotechnol. 2011;10(1):103-7.

15. Shang TW. Diversity and Bioactivities of Endophytic Fungi from Medicinal Plant Andrographis paniculata (Hempedu Bumi), [PhD's Dissertation]. Malaysia: Monash University; 2016.

16. Munawar M, Muharni M, Ivantri I. Chemical constituen from an endophytic fungus Aspergillus sp (SbD5) isolated from sambiloto (Andrographis paniculata Nees). Microbiol Indones.
2015;9(2):82-8. https://doi.org/10.5454/mi.9.2.5

17. Riga R, Happyana N, Hakim EH. Sesquiterpenes produced by Pestalotiopsis microspora HF 12440 isolated from Artocarpus heterophyllus. Nat Prod Res. 2020;34(15):2229-31. https://doi. org/10.1080/14786419.2019.1578764

18. Ali H, Khyber MT, Khyber MS. Antimicrobial potentials of Eclipta alba by disc diffusion method production of biomass and medicinal metabolites through in vitro cultures in ajuga bracteosa view project establishment of plant in vitro cultures in Artimisia species for production of Indus. Afr J Biotechnol. 2011;10(39):7658-67.

19. Zaidan MR, Rain AN, Badrul AR, Adlin A, Norazah A, Zakiah I. In vitro screening of five local medicinal plants for antibacterial activity using disc diffusion method. Trop Biomed. 2005;22(2):165-70.

PMid:16883283

20. Khairi VA, Etika SB, Suryelita S, Ulfah M, Riga R. Study of the antibacterial activity of endophytic fungus that colonize with the twig of Andrographis paniculata. Eksakta. 2021;21(2):137-44.

21. Riga R, Happyana N, Quentmeier A, Zammarelli C, Kayser O, Hakim EH. Secondary metabolites from Diaporthe lithocarpus isolated from Artocarpus heterophyllus. Nat Prod Res. 2019;35(14):1-5. $\quad$ https://doi.org/10.1080/14786419.2019. 1672685

22. Handayani D, Ananda N, Artasasta MA, Ruslan R, Fadriyanti $O$, Tallei TE. Antimicrobial activity screening of endophytic fungi extracts isolated from brown algae Padina sp. J Appl Pharm Sci. 2019;9(3):9-13. https://doi.org/10.7324/japs.2019.90302

23. Haghgoo R, Mehran M, Afshari E, Zadeh HF, Ahmadvand M. Antibacterial effects of different concentrations of Althaea officinalis root extract versus $0.2 \%$ chlorhexidine and penicillin on Streptococcus mutans and Lactobacillus (in vitro). J Int Soc Prev Community Dent. 2017;7(4):180-5.

PMid:28852633

24. Othman L, Sleiman A, Abdel-Massih RM. Antimicrobial activity of polyphenols and alkaloids in middle eastern plants. Front Microbiol. 2019;10:911. https://doi.org/10.3389/ fmicb.2019.00911

PMid:31156565

25. Bouarab-Chibane $L$, Forquet $V$, Lantéri $P$, Clément $Y$, LéonardAkkari L, Oulahal N, et al. Antibacterial properties of polyphenols: Characterization and QSAR (Quantitative structure-activity relationship) models. Front Microbiol. 2019;10:829. https://doi. org/10.3389/fmicb.2019.00829

26. Kursia S, Aksa R, Nolo MM. Antibacterial properties of endophytic fungi isolated from daun kelor (Moringa oleifera Lam.). Pharmauho J Farmasi Sains Kesehatan. 2018;4(1):30-3. https://doi.org/10.33772/pharmauho.v4i1.4631

27. Pandey A, Negi PS. Phytochemical composition, in vitro antioxidant activity and antibacterial mechanisms of Neolamarckia cadamba fruits extracts. Nat Prod Res. 2018;32(10):1189-92. https://doi.org/10.1080/14786419.2017.1 323209

PMid:28475362

28. Liu X, Dong M, Chen X, Jiang M, Lv X, Zhou J. Antimicrobial activity of an endophytic Xylaria sp. YX-28 and identification of its antimicrobial compound 7-amino-4-methylcoumarin. Appl Microbiol Biotechnol. 2008;78(2):241-7. https://doi.org/10.1007/ s00253-007-1305-11

29. Xu WF, Hou XM, Yao FH, Zheng N, Li J, Wang CY, et al. Xylapeptide $\mathrm{A}$, an antibacterial cyclopentapeptide with an uncommon L-pipecolinic acid moiety from the associated fungus Xylaria sp. (GDG-102). Sci Rep. 2017;7(1):6937. https:// doi.org/10.1038/s41598-017-07331-4

PMid:28761094 